\title{
The Effect of Social Media Marketing on Purchase Intention (Evidence from Indonesia)
}

\author{
Sutopoh Kusumo ${ }^{1, *}$ Agus Rahayu ${ }^{2,}$ Lili Adi Wibowo ${ }^{3,}$ Heny Hendrayati ${ }^{4}$ \\ ${ }^{1}$ Universitas Pendidikan Indonesia \\ ${ }^{2}$ Universitas Pendidikan Indonesia \\ ${ }^{3}$ Universitas Pendidikan Indonesia \\ ${ }^{4}$ Universitas Pendidikan Indonesia \\ *Corresponding author. Email: sutopoh.k@gmail.com
}

\begin{abstract}
The use of social media today in the marketing world is superior to other advertising media. Some social media that are often used, such as WhatsApp, Facebook, Twitter, blogs, websites, and others, are used dynamically from year to year. Social media can increase consumer knowledge and can increase the interest and purchasing power of a product. This research uses descriptive and verification methods with a Con-firmatory Factor Analysis as an analysis tool in the data processing. Empirical data is collected through a questionnaire given to social media users. Moreover, the study shows eight variables of social media mar-keting dimensions, namely offering through social media, social media that are easy to use, product info through social media, the benefits of using social media, looking for info through social media, time, buyer at-titude, and purchase intention.
\end{abstract}

Keywords: social media marketing, purchase intention, social media, marketing.

\section{INTRODUCTION}

The use of social media today in the world of marketing is superior compared to other advertising media. This is in line with the Industrial Revolution 4.0, where IoT-based thinking (internet of thinking) is used as strategic steps to advance a company organization, decisions, and policies [1]. renewal and change in promoting its products and adaptation speed to follow technological trends must be a challenge and motivation to compete in the business world [2].

Some social media are often used, for example, WhatsApp, Facebook, Twitter, blogs, websites, and others [1] and utilized dynamically from year to year. Social media can drive the desire to buy from consumers because it has several ad-vantages compared to conventional promotion. Technological progress is so fast that particular social media will continue to change over time, for example, the use of BlackBerry, which is no longer in use. This is mainly due to social media users' attitudes, who are always changing and thinking practically but multiuse.

Social media can increase consumer knowledge and increase the interest and purchasing power of a product [2] because social media can provide complete information about a product. Consumers can interact with producers through social media such as Facebook and Twitter [3]

Besides increasing the knowledge of social media, users also expect ease of convenience, for example, the ease of comparing prices, the ease of finding certain products, the ease of finding sources of products, and so on [4] so that consumers feel comfortable which ultimately increases the desire to buy. Humans always want a change for the better. Therefore, humans always want to develop their knowledge, and promotion through Social Media can change consumers' behavior in choosing specific products. 
Companies must improve production cost efficiency so that social media can make cost savings in promotion but not reduce consumer interest and even increase purchasing power [1].

Besides the benefits of using social media, such as increasing knowledge, ease of use, and cost-efficiency, that will also increase the interest in spending on social media and encourages people to come back to buy [5]

Based on the description above, the adjudicator wants to conduct further research under the title "The Effect of Social Media Marketing on Purchase Intention (Evidence from Indonesia)".

\subsection{Purchase intention}

Intention is a psychological aspect that has a significant influence on attitudes and behavior. Consumer assessment of a product depends on their knowledge of information about the actual function of the product. Thus, consumers interested in purchasing a product are influenced by the information received [6].

Purchasing intention in a product can also occur with the influence of other people who are trusted by potential consumers. Consumers also sometimes feel very interested in sharing information about products obtained through advertisements, the experiences of people who have used them, and the urgent need for a product. In the evaluation stage of the purchase decision process, consumers form a liking/interest for brands in a set of choices. Consumers may also form an interest in the product they most like [7].

Reference [8] in [9], purchase intention can be identified through the following indicators: (1) Transactional interest, namely the tendency to buy products. (2) Referential interest, namely the tendency for someone to refer products to others. (3) Preferential interest, namely interest that describes the behavior of a person who has a primary preference for the product. This preference can only be changed if something happens to the preferred product. (4) Explorative interest describes the behavior of a person who is always looking for information about the product he is interested in and looking for information to support the favorable properties of the product.

\subsection{Social media marketing}

Promotion is an activity that communicates product advantages and persuades target customers to buy it [10]. Meanwhile, social media allows consumers to share information, text, images, audio, and video with companies [7].

From the two definitions above, it can be concluded that social media is a means of exchanging information between individuals and can be used as a means of company promotion.

Besides that, social ads reach the audience in which you have invested a lot of money and time into nurturing. You can see which audience is engaging the most, so you can ensure that your ads are being bought correctly and you are growing your fan based on true date. There are several promotions through social media: Facebook, Twitter, Linkedin, and Instagram.

\subsection{Conceptual Framework And Hypotheses}

Based on the theory and conceptual framework previously stated, the hypothesis can be developed by fig. 1 .

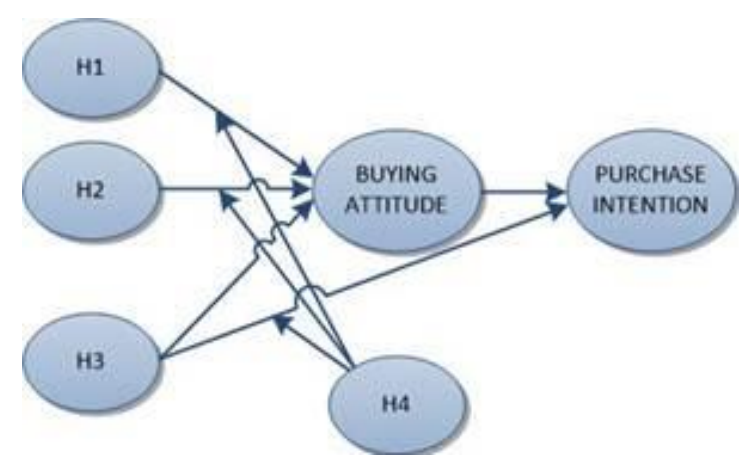

Figure 1. Conceptual framework

H1: Buying attitude affects Purchase Intention

H2: Marketing Via Social Media influences Buying Attitude

H3: Social Media influences Buying attitude in choosing products

H4: Does the ease of use of Social Media affect Buying Attitude and Purchase Intention

\section{METHODS}

This research is quantitative to analyze the effect of social media marketing on purchase intention. The unit of analysis used is a variety of diverse communities from the housing environment where researchers live, HRD community, motorcycle community, study community, and others. The amount obtained based on data entered from December 23 to December 31, 2019, amounted to 328 respondents. This research uses a Confirmatory Factor Analysis as an analysis tool in data processing. 


\section{RESULT AND DISCUSSION}

\subsection{RESULT}

\subsubsection{Assessment of Measurement Models}

Significant Value of Offers via Social Media: 0.000, Product Info Via Social Media: 0.000, Benefits of Using Social Media: 0.000 less than $0.05(<0.05)$, then all three have a significant influence on buying interest. While the sense of easy-to-use Social Media: 0.056, Looking for product info via Social Media: 0.539 and a faster time: 0.886 Significant value is greater than 0.05 (>0.05) then the three do not significantly affect the attitude of buying.

$\mathrm{R}$ Square's value is 0.447 , which means the influence of offers via Social Media, Via Medsos Product Info, and the Benefits of Using Social Media has an effect of $44.7 \%$, while the other $55.3 \%$ is influenced by other variables not included in this study. Direct influence can show by fig. 2 .

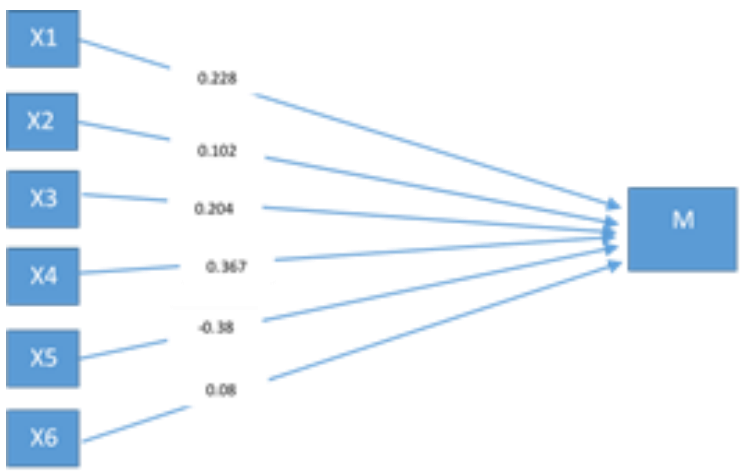

Figure 2. Direct influence (Path Coefficient Model I)

Significant Value of Sense of Using Medsos: 0.01, Product Info via Medos: 0,000, Benefits of using Medsos: 0,000, Time: 0.001, and Buyer Attitude: 0,000 less than $0.05 \quad(<0.05)$, it significantly influences Purchase to Buy. Whereas Via Medsos Offer: 0.08, Find Via Medsos info: 0.710 does not significantly influence Intention to Buy greater than 0.05 (> 0.05).

$\mathrm{R}$ Square's value is 0.627 , which means that the sense of ease using Social Media, Product Info via Medos, the benefits of using Social Media, Time, and Attitude to Buy effects $62.7 \%$ while others $37.3 \%$ are influenced from other variables not included in this study. Indirect of effect can show by fig. 3 .

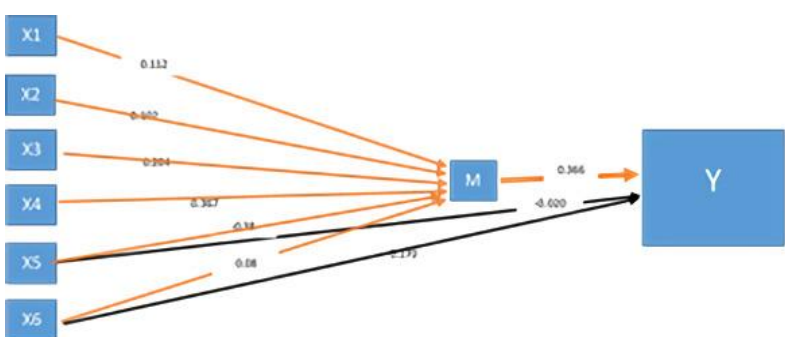

Figure 3. Indirect Effect of (Path Coefficient Model II)

\subsubsection{Assessment Of Structural Models}

Table 1 below shows seven factors with eigenvalues of more than 1 , which is 5,315. Based on Table 1 , we can conclude that those factors can define variation $79,93 \%$. In the last step, CFA should be analyzed to conclude variables that determinants the structural model in this study.

Table 1. Total Variance Explained

\begin{tabular}{|l|c|c|c|c|c|c|}
\hline \multirow{2}{*}{$\begin{array}{c}\text { Compo } \\
\text { nent }\end{array}$} & \multicolumn{3}{|c|}{ Initial Eigenvalues } & \multicolumn{3}{c|}{$\begin{array}{c}\text { Extraction Sums of } \\
\text { Squared Loadings }\end{array}$} \\
\cline { 2 - 7 } & Total & $\begin{array}{c}\text { \% of } \\
\text { ariance }\end{array}$ & $\begin{array}{c}\text { Cumulati } \\
\text { ve \% }\end{array}$ & Total & $\begin{array}{c}\text { \% of } \\
\text { Variance }\end{array}$ & $\begin{array}{c}\text { Cumula } \\
\text { tive \% }\end{array}$ \\
\hline 1 & 5.315 & $\begin{array}{l}75.93 \\
4\end{array}$ & 75.934 & $\begin{array}{l}5.13 \\
7\end{array}$ & 75.934 & 75.934 \\
\hline 2 & .522 & 7.453 & 83.837 & & & \\
\hline 3 & .430 & 6.138 & 89.525 & & & \\
\hline 4 & .279 & 3.981 & 93.506 & & & \\
\hline 5 & .250 & 3.574 & 97.080 & & & \\
\hline 6 & .118 & 1.680 & 98.759 & & & \\
\hline 7 & .087 & 1.241 & 100.00 & & & \\
\hline
\end{tabular}

Table 2 below shows that all of the variable's value is more than 0,5 , which means that all of the variables are factors that determine $\mathrm{CP}$. This study proves that offering through social media, easy-to-use social media, product info through social media, benefits of using social media, looking for info through social media, timing, and buying attitude value are determinant factors of purchase intention.

Table 2. Component Matrix

\begin{tabular}{|c|c|}
\hline & Component \\
\cline { 2 - 2 } & $\mathbf{1}$ \\
\hline Offering through Social Media & .893 \\
\hline Easy to Use Social Media & .931 \\
\hline Product Info Trough Social Media & .922 \\
\hline Benefits of Using Social Media & .873 \\
\hline Look for Info through Social Media & .820 \\
\hline Timing & .896 \\
\hline Buying Attitude & .751 \\
\hline
\end{tabular}

Extraction Method: Principal Component Analysis 1 component extracted 


\subsection{Discussion}

The results show the significant value of Buying attitude, which means it has a significant direct effect on Purchase Intention, and $\mathrm{H} 1$ is proven.

It also shows the distribution of offers through social media affects the Buying Attitude, as well as the Purchase Intention directly affects. Meanwhile, the Ease of Use in Social Media has no significant effect on Buying Attitudes while directly affecting Purchase Intention.

Information satisfaction obtained through Social Media has a real influence on Buying Attitudes as well as on Purchase Intention, which has a significant effect. Likewise, the benefits obtained by using Social Media have a significant effect on Buying At-titudes and Purchase Intention.

The ease of finding products on Social Media does not directly influence the Buying Attitude. The ease of finding info via social media and the faster time of searching for products through Social Media. Towards the direct influence of Purchase Intention.

The ease of searching for info through social media has no significant effect, while the faster time in searching for products through Social Media directly affects Intention to buy.

This study's results are in line with the results of research conducted by [12] in their research paradigm. Buying interest is influenced by social media, which is carried out through consumer perceptions of products. In theory, social media is an essential communication tool and has a high role in consumer purchase interest

\section{CONCLUSION}

Buying attitude through social media is influ-enced by offers through social media, product info through, and the amount of information using social media. Buying attitude directly affects Purchase In-tention.

Sense of Using Social Media, Product Info through Social Media and the Many Benefits of using Social Media, and Saving time directly affect Purchase Intention.

\section{ACKNOWLEDGMENT}

We would like to express our gratitude to Universitas Pendidikan Indonesia who have facilitated the research to its completion.

\section{REFERENCES}

[1] X.Y. Leung, B. Bai, K.A. Stahura, "The marketing effectiveness of social media in the hotel industry a comparison of Facebook and twitter," J. Hosp. Tour. Res., Vol. 39, no. 2, pp. 147-169, 2015.

[2] M. Hamilton, V.D. Kaltcheva, A.J. Rohm, "Social media and value creation: the role of interaction satisfaction and interaction immersion," J. Interact. Market., vol. 36, pp. 121-133, 2016.

[3] Adjei, T. Mavis, H.N. Charles, and M.N. Stephanie, "Enhancing relationships with customers through online brand communities," MIT Sloan Management Review., vol. 53, pp. 22-4, 2012.

[4] R.G. Duffett, "Facebook advertising's influence on intention to purchase and purchase amongst millennials," Internet Res., vol. 25, no. 4, pp. 498 526, 2015.

[5] Z. Zhu, J. Wang, X. Wang, X. Wan, "Exploring factors of user's peer-influence behavior in social media on purchase intention: evidence from QQ," Comput. Hum. Behav., vol. 63, pp. 980-987, 2016.

[6] L.G. Schiffman, and Kanuk, Consumer Behaviour. USA : New Jersey Prentice Hall, 2012.

[7] K. Philip and L.K. Kevin, Marketing Management, $15^{\text {th }}$ Edition. New Jersey: Pearson Pretice Hall, Inc, 2016.

[8] A. Ferdinand, Metode Penelitian Manajemen. Semarang: Badan Penerbit Universitas Diponegoro, 2006.

[9] Sulistyari, N. Ikanita, "Analisis pengaruh citra merek, kualitas produk, dan harga terhadap minat beli produk oriflamme (studi kasus mahasiswi fakultas ekonomika dan bisnis jurusan manajemen Universitas Diponegoro Semarang)," Diponegoro J. of Management., vol 1, no. 1, 2012.

[10]Armstrong, Kotler, "Marketing an introducing prentice hall" twelfth edition. England : Pearson Education, Inc, 2015.

[11]P. Goodman, "Everything you need to know about social media ads," 2013.

[12] Maoyan, Zhujunxuan, and Sangyang, "Consumer purchase intention research based on social media marketing,” Int. J. Bus. Soc. Sci., 2014. 